Scientific Review - Engineering and Environmental Sciences (2021), 30 (1), 29-37

Sci. Rev. Eng. Env. Sci. (2021), 30 (1)

Przegląd Naukowy - Inżynieria i Kształtowanie Środowiska (2021), 30 (1), 29-37

Prz. Nauk. Inż. Kszt. Środ. (2021), 30 (1)

http://iks.pn.sggw.pl

DOI 10.22630/PNIKS.2021.30.1.3

Zainab A. NEAMAH, Munaf A. Al-RAMAHEE

University of Al-Qadisiyah, College of Engineering

\title{
Strengthening of bi-axially loaded RC slab-column connection using steel plates and stiffeners
}

Key words: bi-axial loads, eccentric load, flat slab, strengthening, steel plates

\section{Introduction}

Reinforced concrete flat slabs are slabs that rest directly on columns without beams. Flat slabs are widely used in multi-storey buildings such as garages and office buildings, due to their many benefits, including ease of construction, simple reinforcements and freedom of architectural design, etc. The slab-column connection regions are the most important part due to its failure by punching shear. Punching shear failure occurs suddenly without any signs due to the transmission of high loads and moments greater than the design resistance which comes from the change in design or using bad constructions materials. Some of these loads are eccentric due to the influence of winds, creep, unbalanced loads, different shrinkage and unequal spans. Punching shear can be avoided by increasing the ultimate strength of the slab.

Different methods have been employed to increase the ultimate strength of flat slabs, including internal and external strengthening (Al-Khekany, Al-Ramahee \& Al-Yassri, 2020). The internal strengthening involves; increasing the thickness of the slab, increasing the flexural reinforcement, and using the shear reinforcement. On the other hand, the external strengthening includes the use of fiber reinforced polymer (FRP) strips, the use of drop panel or the column capitals, and the use of steel plates (Al-Ramahee, Chan, Mackie, Ghasemi \& Mirmiran, 2017). Shaaban (2013), Abbas, Abadel, Almusallam \& Al-Salloum (2015), Meisami, Mostofinejad and Nakamura (2015) investigated the effect of using FRP strips as a strengthening method with different shapes and numbers. This method was effective to increasing the ultimate capacity of flat slab. Marzouk, Emam and Sameh Hilal (1998), Inácio, Ramos, Lùcio and Faria 
(2013) experimentally studied the effect of increasing the concrete strength on the behavior of flat slab through using high concrete strength. This method was good for increasing the stiffness of flat plates. Alam and Amanat (2013), Inácio et al. (2013), Jang and Kang (2019) investigated the effect of increasing the flexural reinforcement of flat slab with different ratios. They concluded that the increasing in the flexural reinforcements has a good effect on the behavior of flat plates. Abdelaziz, El-Nawawy, El-Karmoty and Abu-Beah (2019) investigated the behavior of RC flat slab that strengthened with added of ultra-high strength concrete drop panel with different dimensions of drop panels. This method showed a good result, where when the thickness of drop panel was increased, the ultimate load and stiffness increased. Ebead and Marzouk (2002) investigated the effect of using steel plates and steel bolts with different numbers of steel bolts and shapes on the ultimate capacity of slabs. Their results showed the using of steel plates is a good effective strengthening technique. Elbakry and Allam (2015) studied the effect of using externally bonded steel plates with different thickness and different numbers of shear studs on the slab behavior. The use of this method was considered a good method to strengthened flat slab against punching shear stresses. Kadhim and Ammash (2019) investigated the effect of using steel stiffeners and column capital with different dimensions and different numbers of stiffeners. They found that the using of steel plates improve the behavior of slab-column connection.

Available literature shows that the strengthening of slab-columns connec- tions using steel plates and steel stiffeners has not got enough attention previously. Also, there was very little researchers studied the effect of bi-axial loads on punching shear behavior of slab-columns connections. This paper investigates the enhancing the punching shear strength of slab-column connection by using steel plates and stiffeners under the bi-axial loads. Different plates and stiffeners sizes were included in this study.

\section{Experimental program}

The experimental program included testing of four RC slabs under bi-axial load. One slab was tested as control slab without strengthening, and other three RC slabs were test with the benefit of applying steel plate and stiffeners to enhance the slab-column region against punching shear failure. The dimensions of slabs are $1,600 \times 1,600 \mathrm{~mm}$ with a total thickness of $100 \mathrm{~mm}$. The RC column dimensions are $200 \times 200 \mathrm{~mm}$ with a height of $300 \mathrm{~mm}$. A column cap is used at the top of the column to avoid crushing the columns and highlighting the biaxial loads. A column cap dimensions are $500 \times 500 \mathrm{~mm}$ with thickness of $200 \mathrm{~mm}$. The flexural reinforcement ratio was used to be $1.26 \%$. The details of tested specimens are shown in Table 1. The letters SS referred to strengthened slab. The first number $(0,6$, and 8$)$ that follow the letter $S$ refers to the steel plates dimensions $(0,600$ and $800 \mathrm{~mm})$. The second number $(0,2$ and 3$)$ refers to number of stiffeners. The reinforcement details for slab, column and column's cap for SS00 slab are shown in Figure 1. These details are identical for other 
TABLE 1. Specimens details

\begin{tabular}{|c|c|c|c|c|c|}
\hline Symbol & $\begin{array}{c}\text { Compressive } \\
\text { strength } \\
{[\mathrm{MPa}]}\end{array}$ & $\begin{array}{c}\text { Flexural } \\
\text { reinforcement } \\
\text { ratio } \\
{[\%]}\end{array}$ & $\begin{array}{c}\text { Total dimensions } \\
\text { of slab plates } \\
{[\mathrm{mm}]}\end{array}$ & $\begin{array}{c}\text { Number } \\
\text { of stiffeners }\end{array}$ & $\begin{array}{c}\text { Stiffener's } \\
\text { dimensions } \\
{[\mathrm{mm}]}\end{array}$ \\
\hline SS00 & \multirow{4}{*}{33} & \multirow{4}{*}{1.26} & - & - & - \\
\hline SS62 & & & $600 \times 600$ & 2 & $200 \times 200$ \\
\hline SS63 & & & $600 \times 600$ & 3 & $200 \times 200$ \\
\hline SS83 & & & $800 \times 800$ & 3 & $300 \times 300$ \\
\hline
\end{tabular}

SS00

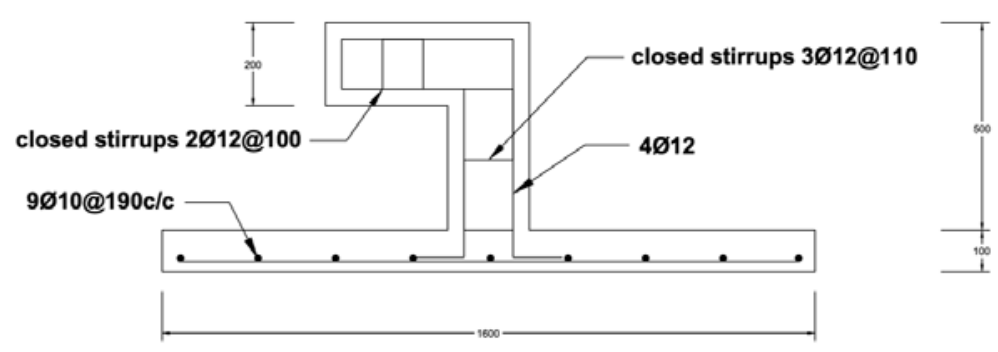

SS62
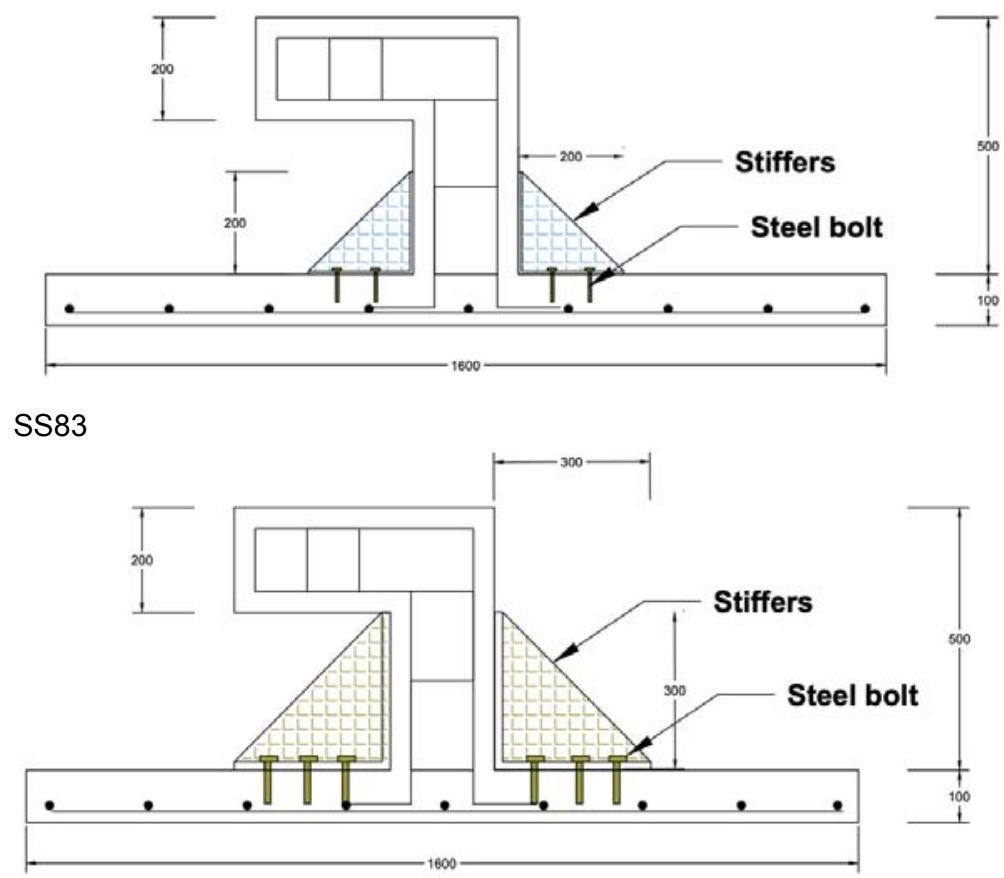

FIGURE 1. Specimens geometry and reinforcement details (all dimensions in $\mathrm{mm}$ ) 
a

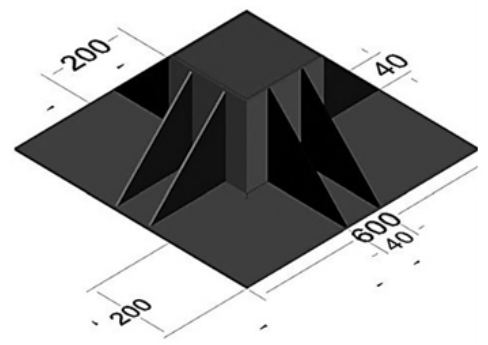

b

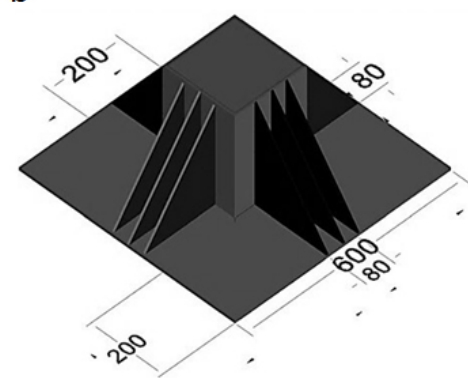

FIGURE 2. Details of steel plate and stiffeners (all dimensions in $\mathrm{mm}$ ): a - plate with two stiffeners; $\mathrm{b}$ - plate with three stiffeners

specimens. Three slabs are strengthened using steel plates and steel stiffeners. The thickness of the steel plates is $6 \mathrm{~mm}$. The dimensions of the steel plate was $600 \times 600$ and $800 \times 800 \mathrm{~mm}$ in the slab-column connection region and it was fixed to the slab using steel bolts. The steel stiffeners are cut in the form of a right-angled triangle with dimensions of $200 \times 200$ and $300 \times 300 \mathrm{~mm}$. Figure 2 shows the sketch of the steel plate and stiffeners. The stiffeners are placed and welded to link the column plates and the slab plates.
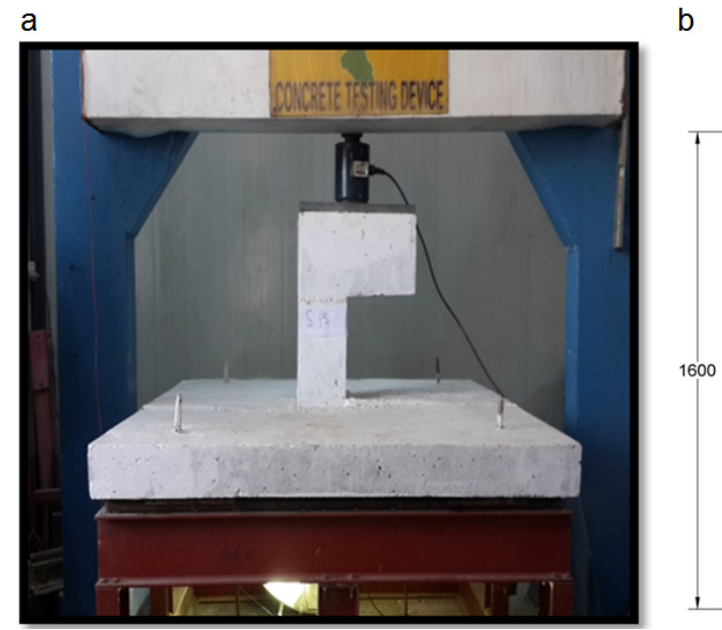

\section{Experimental test}

A total of four simply supported specimens of RC slab-column connection under biaxial load were tested in this study. One of these slabs was examined as a reference slab (SS00), and the other three slabs were strengthened using steel plates and stiffeners. The specimens are rested along the four edges on knife edges placed on steel frames. The load was applied on 40-mm thick steel plate using load-controlled hydraulic jack with a capacity of $1,000 \mathrm{kN}$. A linear variable

b

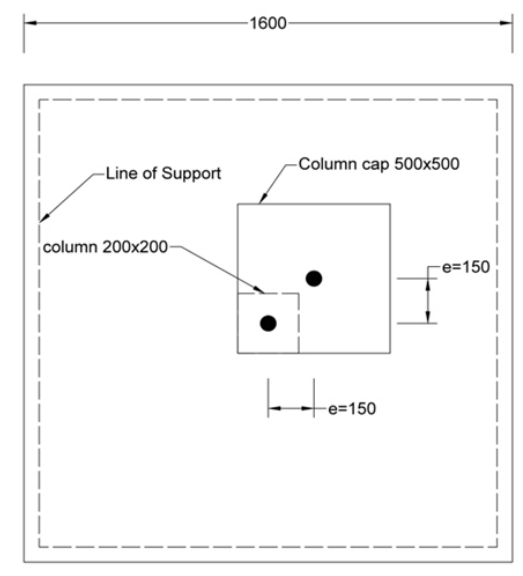

FIGURE 3. Test set-up under biaxial load: $a$ - test set-up; $b$ - top view sketch (all dimensions in mm) 
displacement transformer (LVDT) was used to record the central deflection of the slabs. The top and bottom face of all specimens were observed for cracks development. The test continued until an excessive deflection was recorded and the column had penetrated the slab. A computerized data acquisition device was used to record the test results. The test setup and sketch for bi-axially loaded slabs is shown in Figure 3.

\section{Results and discussion}

\section{Ultimate load and deflection}

The results obtained from experimental tests of the slab column connections strengthened with steel plates and stiffeners under bi-axial load showed that the ultimate loads for SS62, SS63 and SS83 increased by about 71, 72 and $111 \%$, respectively when compared with SS00. Also, the steel plate and stiffeners delayed the first crack load 114\% for SS62, 90\% for SS63 and 29\% for SS83 as shown in Table 2. This enhancement can be related to the fact that the strengthening method was effective to increase the critical section which mean increased area that resist the high stresses. Also, it increases the flexural rigidity for the connection region. The deflection at ultimate load there was an increasing by about 54\% for SS62, 75\% for SS63 and by about 94\% for slab SS83. Also, the deflection at cracking load level there was increased by about $252 \%, 148 \%$ and $44 \%$ for SS62, SS63 and SS83, respectively when compared with SS00.

\section{Failure mode}

All slabs in this study have the same behavior of the failure. As the applied load increased, the cracks begin to form, and they extended from the edges of the specimens towards the center and it is intersected with the locations of bolts in the strengthened specimens. It can be observed that the failure of strengthened specimens became more ductile than the reference slab SS00 (Figs. 3 and 4). Also, the slabs strengthened with steel plates (SS62, SS63 and SS83) have cracks width less than the reference slab.

\section{Load deflection relationship}

The load-deflection curves for the slabs SS62, SS63, SS83 compared to SS00 are shown in Figures 5 and 6, respectively. It can be shown that the specimens strengthened with steel plates have more stiffness, more ductile fail-

TABLE 2. Summary of test results

\begin{tabular}{|l|c|c|c|c|c|c|}
\hline Slab & $\begin{array}{c}\text { First crack } \\
\text { load } \\
{[\mathrm{kN}]}\end{array}$ & $\begin{array}{c}\text { Cracking } \\
\text { deflection } \\
{[\mathrm{mm}]}\end{array}$ & $\begin{array}{c}\text { Ultimate load } \\
{[\mathrm{kN}]}\end{array}$ & $\begin{array}{c}\text { Ultimate } \\
\text { deflection } \\
{[\mathrm{mm}]}\end{array}$ & $\begin{array}{c}\text { Increasing in } \\
\text { ultimate load } \\
{[\%]}\end{array}$ & $\begin{array}{c}\text { Increasing } \\
\text { in ultimate } \\
\text { deflection } \\
{[\%]}\end{array}$ \\
\hline SS00 & 21 & 0.64 & 103 & 15.42 & - & - \\
\hline SS62 & 45 & 2.27 & 176 & 23.73 & 71 & 54 \\
\hline SS63 & 40 & 1.59 & 177 & 26.94 & 72 & 75 \\
\hline SS83 & 27 & 0.93 & 217 & 29.91 & 111 & 94 \\
\hline
\end{tabular}


SS00

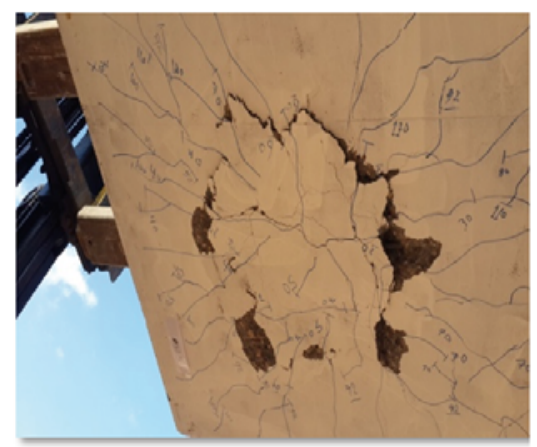

SS63

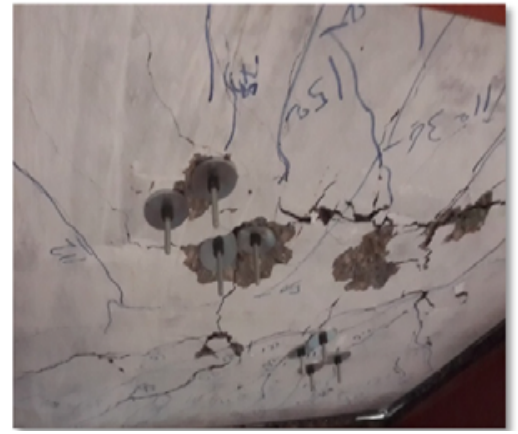

FIGURE 4. Cracks patterns

ure, and higher ultimate load compared to reference specimens (SS00). The increasing in the number of stiffeners from two stiffeners in SS62 to three stiffeners in SS63 has no significant effect on the behavior of specimens for $600 \mathrm{~mm}$ steel plate strengthened specimens. Figure 7 shows the comparison between the strengthened slab column connection behavior using 600- and $800-\mathrm{mm}$ steel plate. It can be noticed that when steel plates dimensions increased, the ultimate load increased by about $23 \%$ for SS83 when compared with slab SS62 and SS63. Also, when the dimensions of steel plates increased, the stiffness and ductility of connection region increased.
SS62

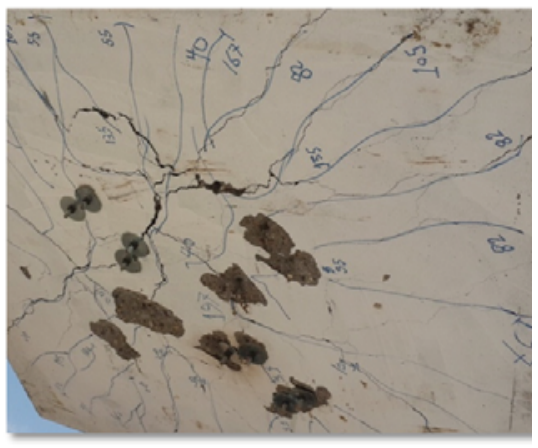

SS83

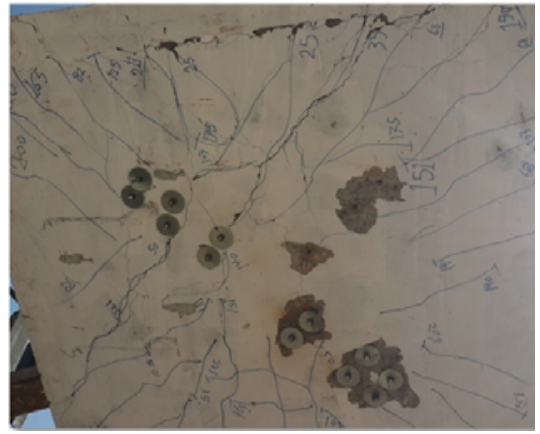

This enhancement of strengthening because of steel plates worked as a column capital which lead to an increasing in the critical sections of column which mean increasing the area that resist the high stresses transformed form column to slab.

\section{Conclusions}

Strengthened slab-column connection with the steel plates and stiffeners enhanced both the stiffness, also the failure mode of the slab-columns connection became more ductile.

The connection region that subjected to bi-axial load and strengthened with 


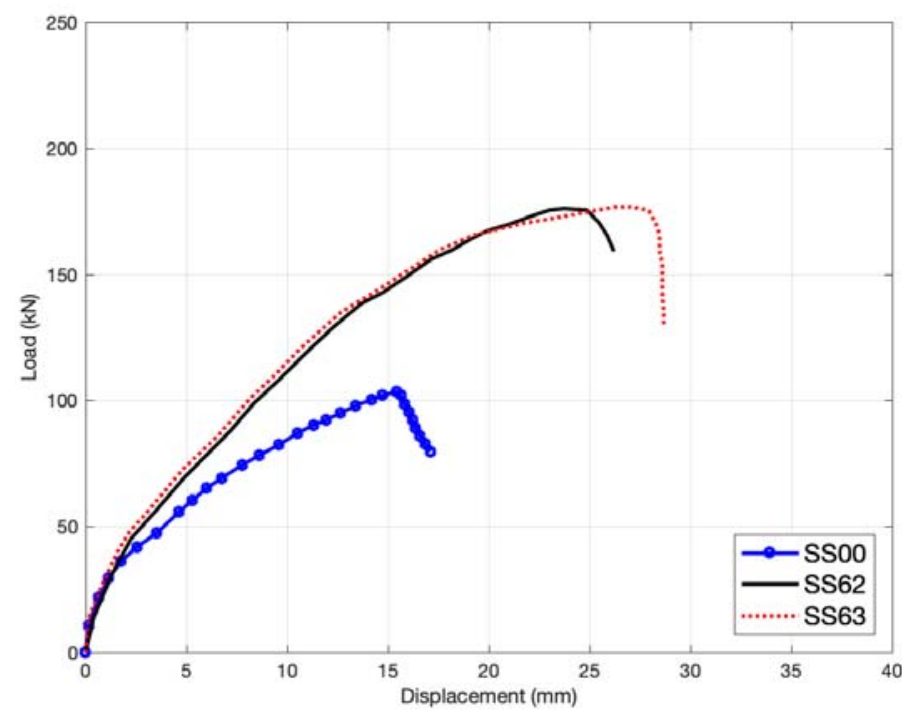

FIGURE 5. Comparison results of 600-mm steel plate

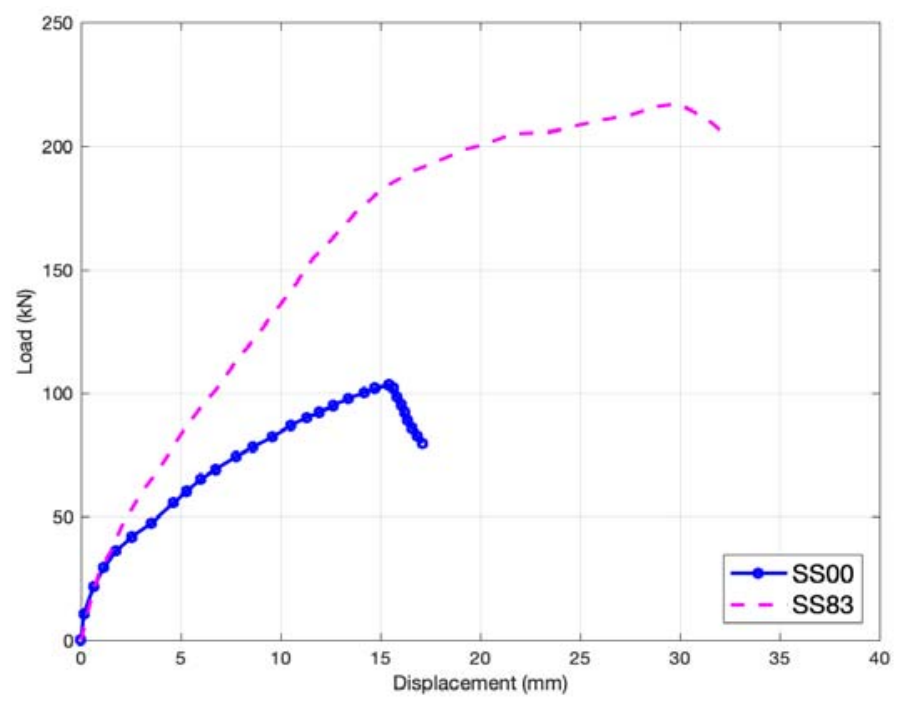

FIGURE 6. Comparison results of $800-\mathrm{mm}$ steel plate

steel plate and stiffeners have ultimate capacity more than the reference specimen by about $71 \%$ for SS62, $72 \%$ SS 63 and $111 \%$ for SS83.

It can noticed that the connection with steel plates dimensions $800 \times 800 \mathrm{~mm}$
(SS83), the ultimate load and deflection increased by about $23 \%$ and $26 \%$, respectively when compared to SS62 and by about $23 \%$ and $11 \%$, respectively when compared to SS63 which they strengthened by a $600 \times 600 \mathrm{~mm}$ steel plate. 


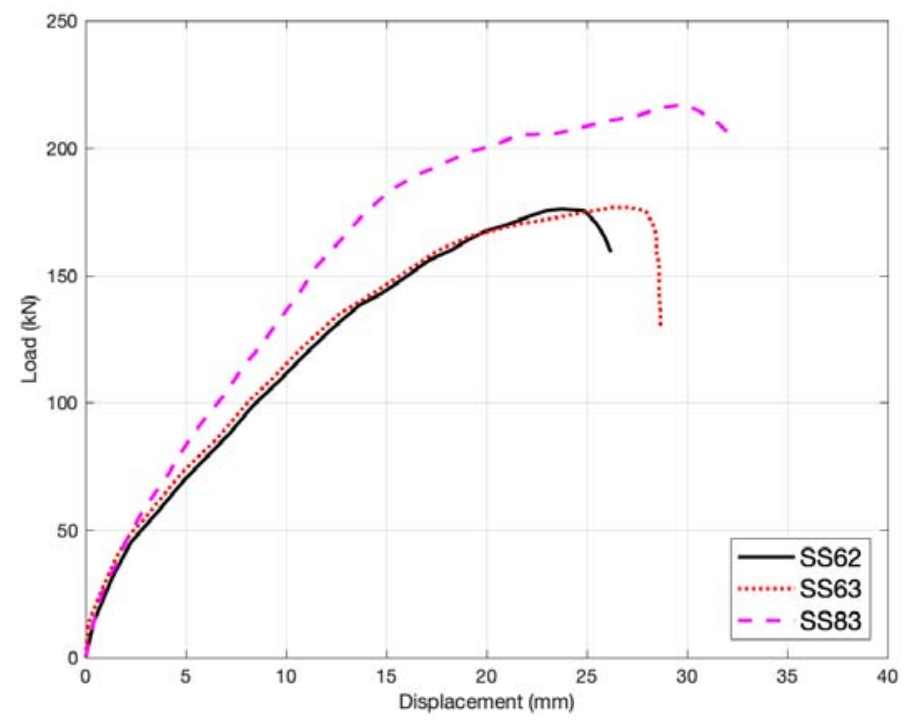

FIGURE 7. Comparison results of 600- and $800-\mathrm{mm}$ steel plate

It can be observed from the results that the larger steel plate (SS83), the less the cracks width compared to the specimen with $600 \times 600 \mathrm{~mm}$ steel plate despite of the number of stiffeners.

The results showed the using three stiffeners instead of two stiffeners with $600 \times 600 \mathrm{~mm}$ plate has no significant effect on the ultimate load and the behavior of slab column connection.

\section{References}

Abbas, H., Abadel, A.A., Almusallam, T. \& Al-Salloum, Y. (2015). Effect of CFRP and TRM strengthening of RC slabs on punching shear strength. Latin American Journal of Solids and Structures, 12(9), 1616-1640.

Abdelaziz, H., El-Nawawy, O., El-Karmoty, H. \& Abu-Beah, A. (2019). Behavior of flat slabs using ultra high strength concrete under the effect of eccentric punching shear. International Journal of Scientific and Engineering Research, 10(4), 528-540.

Alam, A.M.J. \& Amanat, K.M. (2013). Fe analysis on the effect of flexural steel on punch- ing shear of slabs. International Journal of Engineering Research and Technology, 2(6), 2878-2901.

Al-Khekany, A.M., Al-Ramahee, M.A. \& Al-Yassri, L.S. (2020). Experimental and numerical investigations of composite concrete steel flexural members with angle shear connectors under negative moment. Periodicals of Engineering and Natural Sciences, 8(4), 2107-2117.

Al-Ramahee, M.A., Chan, T., Mackie, K.R., Ghasemi, S. \& Mirmiran, A. (2017). Lightweight UHPC-FRP composite deck system. Journal of Bridge Engineering, 22(7), 04017022. https://www.doi.org/10.1061/ (ASCE)BE.1943-5592.0001049

Ebead, U. \& Marzouk, H. (2002). Strengthening of two-way slabs using steel plates. Structural Journal, 99(1), 23-31.

Elbakry, H.M. \& Allam, S.M. (2015). Punching strengthening of two-way slabs using external steel plates. Alexandria Engineering Journal, 54(4), 1207-1218.

Inácio, M., Ramos, A., Lúcio, V. \& Faria, D. (2013). Punching of high strength concrete flat slabs - experimental investigation. In Proceedings of the Fib Symposium Tel Aviv 2013. https://www.doi.org/10.13140/2.1.325 1.5849 
Jang, J.I. \& Kang, S.M. (2019). Punching Shear Behavior of Shear Reinforced Slab-Column Connection with Varying Flexural Reinforcement. International Journal of Concrete Structures and Materials, 13(1), 1-14.

Kadhim, S.S. \& Ammash, H.K. (2019). Steel stiffeners for enhancement of slab-column connections. Al-Qadisiyah Journal for Engineering Sciences, 12(4), 199-206.

Marzouk, H., Emam, M. \& Sameh Hilal, M. (1998). Effect of high-strength concrete slab on the behavior of slab-column connections. ACI Structural Journal, 95, 227-237.

Meisami, M.H., Mostofinejad, D. \& Nakamura, H. (2015). Strengthening of flat slabs with FRP fan for punching shear. Composite Structures, 119, 305-314.

Shaaban, I. (2013). Strengthening of reinforced concrete slab-column connection subjected to punching shear with FRP systems. International Journal of Engineering and Technology, 5(6), 657-661.

\section{Summary}

Strengthening of bi-axially loaded RC slab-column connection using steel plates and stiffeners. This paper presented a strengthening technique for enhancement reinforced concrete (RC) slab-column connection behavior using steel plates and steel stiffeners. A bi-axial load was applied with an eccentricity of $150 \mathrm{~mm}$ in both $\mathrm{x}$ and $\mathrm{z}$ directions. Four specimens with dimensions of $1,600 \times 1,600 \times 100 \mathrm{~mm}$ were tested in this research. The steel plate dimensions were chosen to be $600 \times 600$ and $800 \times 800 \mathrm{~mm}$ with $6 \mathrm{~mm}$ thickness. The steel stiffeners are used to support and enhance the steel plate that it is extended from column to the slab-column connection with different dimension. The results showed an improvement in the stiffness of slab and increasing in the ultimate capacity. Also, when the steel plates dimensions increased, the ultimate capacity and stiffness increased. 